\title{
Analiza sytuacji edukacyjnej Romów we Wrocławiu w kontekście rekomendacji wynikającej z piątego raportu monitoringowego Europejskiej Komisji przeciwko Rasizmowi i Nietolerancji (ECRI)
}

Streszczenie: Artykuł został poświęcony analizie sytuacji społeczności romskiej we Wrocławiu oraz realizowanym na terenie miasta formom wsparcia środowisk romskich. Raport został opracowany przez zespół ekspertów zgodnie z rekomendacją wynikającą z piątego raportu monitoringowego Europejskiej Komisji przeciwko Rasizmowi i Nietolerancji (ECRI) dotyczącego Polski, opublikowanego 9 czerwca 2015 roku. Zespół analizował sytuację społeczności romskiej głównie na podstawie spotkań roboczych, wywiadów z ekspertami społecznymi, wizyt monitoringowych oraz danych udostępnionych przez instytucje.

Autor poddaje dyskusji realizowane i wdrażane formy pomocy społeczności romskiej oraz oddziaływaniu wsparcia instytucjonalnego na poprawę jakości życia tej grupy. Kolejną poruszaną kwestią jest diagnoza problemów środowisk polskich i rumuńskich Romów oraz ich marginalizacja. Autor artykułu wskazuje propozycje dobrych praktyk i rozwiązań problemów, z którymi współcześnie borykają się grupy Romów mieszkających nie tylko we Wrocławiu.

Słowa kluczowe: Romowie, wsparcie instytucjonalne Romów, edukacja, integracja społeczności romskiej

\section{Wprowadzenie}

Ekspertyza została opracowana przez grupę specjalistów powołaną Zarządzeniem Wojewody Dolnośląskiego nr 12 z dnia 12 stycznia 2017 roku w sprawie powołania zespotu ekspertów w celu przeprowadzenia analizy sytuacji spoteczności Romów we Wroctawiu, zgodnie z rekomendacją wynikającą z piątego raportu monitoringowego Europejskiej Komisji przeciwko Rasizmowi i Nietolerancji (ECRI) dotyczącego Polski, opublikowanego 9 czerwca 2015 roku. Wykonanie zaleceń miało stać się przedmiotem badania i weryfikacji, 
w związku z tym przygotowano wspomnianą analizę, również w celu określenia strukturalnej i systemowej reakcji na poziomie krajowym, która mogłaby zostać włączona do Programu integracji społeczności romskiej w Polsce na lata 2014-2020.

Grupa pracowała pod przewodnictwem Justyny Matkowskiej - pełnomocnika wojewody dolnośląskiego ds. mniejszości narodowych i etnicznych, przy współpracy podinsp. Barbary Lorenc-Żelisko - pełnomocnika komendanta wojewódzkiego policji we Wrocławiu ds. ochrony praw człowieka, Eweliny Andrasz - pedagoga i nauczyciela wspomagającego edukację uczniów pochodzenia romskiego, z moim udziałem, jako redaktora całości i koordynatora, autora części dotyczącej sytuacji edukacyjnej.

Artykuł, dla którego inspiracją był wspomniany wyżej dokument i prace Zespołu, jest opisem sytuacji społeczności romskiej we Wrocławiu, a konkretnie realizowanych na terenie miasta form wsparcia Romów. Ze względu na konstrukcję tekstu ograniczyłem się przede wszystkim do sfery edukacyjnej, co zresztą jest zgodne z profilem czasopisma. Podejmując się analizy sytuacji społeczności romskiej we Wrocławiu, pragnę zwrócić uwagę na problemy środowisk polskich i rumuńskich Romów oraz realizowane i ciągle jeszcze wdrażane formy wsparcia tych grup. Istotne pozostaje także wskazanie propozycji dobrych praktyk i rozwiązań problemów, z którymi borykają się grupy Romów mieszkających we Wrocławiu, i ta część opracowania będzie rzeczywiście dominująca.

Zatem celem raportu była analiza sytuacji społeczności Romów we Wrocławiu opracowana przez zespół ekspertów i wzbogacona o wywiady z osobami zaangażowanymi w pracę w środowisku romskim, z nim i dla niego (przedstawicieli organizacji romskich, urzędników, członków NGO, pracowników służb socjalnych, doradców zawodowych, asystentów rodzin, pracowników sądów i służb prewencji, straży miejskiej, policji, a także urzędu wojewódzkiego, RPO, badaczy i pracowników naukowych) zgodnie z rekomendacją wynikającą z piątego raportu monitoringowego Europejskiej Komisji przeciwko Rasizmowi i Nietolerancji (ECRI) dotyczącego Polski, opublikowanego 9 czerwca 2015 roku (https://www.coe.int/t/dghl/monitoring/ecri/ country-by-country/poland/pol-cbc-v-2015-20 pol.pdf [dostęp 21.11.2018]).

\section{Przygotowanie raportu}

Zespół analizował sytuację społeczności romskiej głównie na podstawie spotkań roboczych, wywiadów z ekspertami społecznymi, wizyt monitoringo- 
wych oraz danych udostępnionych przez instytucje, takie jak: Gmina Wrocław, Wrocławskie Centrum Rozwoju Społecznego, Miejski Ośrodek Pomocy Społecznej, Europejską Stolicę Kultury Wrocław 2016, Dolnośląski Urząd Wojewódzki, Policja, Straż Miejska, NGOs i innych. Czynności przygotowawcze obejmowały kwerendę materiałów źródłowych, przeprowadzono wywiady z osobami pracującymi, realizującymi projekty ze społecznością romską, a także z samymi Romami, zrealizowano wywiady fokusowe. Prowadzono obserwacje terenowe stanowiące istotny składnik opisu pola problemowego.

W kontekście rekomendacji w sprawie sytuacji Romów wynikających z piątego raportu monitoringowego Europejskiej Komisji przeciwko Rasizmowi i Nietolerancji (ECRI) dotyczącego Polski, problemów sygnalizowanych przez instytucje zewnętrzne, podjęto wysiłek zmierzający do opisu, diagnozy i ewaluacji dotychczasowych instytucjonalnych działań zmierzających do poprawy sytuacji mniejszości romskiej we Wrocławiu (Kwadrans, 2013, 2015, 2016). Pole badawcze dotyczyło m.in. potrzeb edukacyjnych grup romskich, edukacji w kontekście inkluzji społecznej. Wcześniej uczestniczyłem w podobnych badaniach dla władz miasta Wrocławia, Świebodzic i w ramach projektów wspieranych przez Europejski Fundusz Społeczny. Prezentowany tekst jest fragmentem opracowania eksperckiego przygotowanego w 2017 i 2018 roku. Członkowie zespołu brali udział w wielu projektach, co pozwoliło na przyjęcie odpowiedniej perspektywy, a także stanowiło podstawę analiz w oparciu o dotychczasowe doświadczenie. Umożliwia to przekształcanie rzeczywistości społecznej i stosowanie w praktyce wyników badań. Przedmiotem poszukiwań uczyniłem próbę dokonania konceptualizacji i opisu zaangażowania na rzecz społeczności romskiej, a także (co równie ważne) aktywności samych Romów, w kontekście uczestnictwa w działaniach dla i z własnym środowiskiem. Niekiedy stawia się zarzuty dotyczące braku naukowości tego typu opracowań. Tekst wydaje się jednak wartościowy, bowiem stanowi diagnozę wycinka rzeczywistości społecznej, który trudno poddaje się takim opisom. Wskazuję na potrzebę konstruowania programów, projektów, polityk lokalnych wobec Romów. Natomiast dokonując ewaluacji tych ostatnich, również odnoszę się do specyfiki społeczności romskiej.

\section{Społeczność romska we Wrocławiu i realizowane programy oraz projekty}

Romowie to mniejszość etniczna, do której przynależność podczas Narodowego Spisu Powszechnego Ludności i Mieszkań przeprowadzonego w 2011 
roku zadeklarowało 16723 obywateli polskich. Populacja Romów liczy 8604 kobiety oraz 8119 mężczyzn, w tym 10840 osób w wieku produkcyjnym: wykształcenie wyższe - 272 osób (2\%), wykształcenie średnie - 934 (7\%), wykształcenie niższe niż średnie - 11028 (82\%). Liczba Romów aktywnych zawodowo (pracujący i zarejestrowani jako bezrobotni) - 3685, biernych zawodowo - 8029. Na Dolnym Śląsku zamieszkiwało 2028 Romów. Największa grupa romska we Wrocławiu osiedliła się w dzielnicy Brochów, około 400 osób. Są to obywatele polscy, głównie przedstawiciele grupy Bergitka Roma polscy Cyganie wyżynni (karpaccy), którzy od kilkunastu pokoleń prowadzą osiadły tryb życia, a wcześniej zamieszkiwali tereny Podkarpacia. W dzielnicach: Śródmieścia oraz Starego Miasta mieszka kilkadziesiąt rodzin, głównie przedstawicieli grupy Polska Roma - polscy Cyganie nizinni oraz grupy Lowarów i Kełderaszów. Przedstawiciele tych grup podlegają wewnętrznym podziałom rodowym na mniejsze grupy oraz zazwyczaj przestrzegają obyczajowości, tradycji romskich. Na podstawie danych szacowanych odnośnie do znanej liczby uczniów romskich i środowisk objętych pomocą można przypuszczać, że populacja wrocławskich Romów to około 1500-1600 osób.

Ponadto w latach 90. XX wieku we Wrocławiu pojawiły się pierwsze grupy Romów rumuńskich. W latach 2012-2015 na terenie Wrocławia istniało koczowisko zamieszkiwane przez Romów rumuńskich usytuowane przy ul. Paprotnej, na niezabudowanej działce, a od 2012 roku przy ul. Kamieńskiego, na terenie pozostałym po ogródkach działkowych. W tym miejscu należy zaznaczyć, że liczba Romów rumuńskich przebywających na koczowiskach była zmienna ze względu na częste migracje, było to zazwyczaj kilkadziesiąt osób.

Każdego roku rząd przeznacza środki finansowe na realizację wieloletniego programu na rzecz integracji społeczności romskiej w Polsce. Po zakończeniu realizacji Programu na lata 2004-2013 oczywista stała się potrzeba kontynuacji oraz rozwijania dotychczasowych projektów mających na celu poprawę sytuacji edukacyjnej Romów oraz szeroko pojętej integracji tej grupy ze społeczeństwem. Dlatego też w 2014 roku Rada Ministrów przyjęła uchwałę w sprawie ustanowienia wieloletniego Programu Integracji społeczności romskiej w Polsce na lata 2014-2020 (Uchwała Rady Ministrów z dnia 7 października 2014 r.). Beneficjentami są Romowie oraz jednostki samorządu terytorialnego i organizacje pozarządowe. Koordynatorem jest minister właściwy do spraw wewnętrznych i administracji. Dodatkowo w dziedzinie oświaty i edukacji nadzór sprawuje minister właściwy do spraw edukacji narodowej. Na terenie poszczególnych województw programy są koordynowane przez wojewodów. Głównymi obszarami działań są: edukacja, przeciw- 
działanie bezrobociu, bezpieczeństwo, poprawa sytuacji mieszkalno-bytowej i socjalnej. Ponadto działania skoncentrowane są na pogłębianiu wiedzy na temat Romów i ich kultury oraz podtrzymywaniu poczucia romskiej tożsamości kulturowej.

Zgodnie z raportem Najwyższej Izby Kontroli liczba osób przebywających na koczowiskach we Wrocławiu była zmienna, zależna od pory roku oraz wydarzeń i imprez o charakterze masowym. Głównym źródłem utrzymania ich mieszkańców było żebractwo, w które angażowane były także dzieci. Pojedynczy członkowie tych społeczności sporadycznie podejmowali się prac dorywczych. Według informacji zamieszczonych w raporcie (Działania Administracji Publicznej na rzecz ochrony praw mniejszości romskiej w Polsce. 2015, ss. 38-39): „Społeczność romska obu koczowisk zamieszkiwała w prowizorycznych obiektach (barakach), zbudowanych z zebranych surowców wtórnych. W obiektach tych nie było żadnych instalacji sanitarnych. Źródłem ciepła były piece, służące zarówno do ogrzewania, jak i gotowania. Energia elektryczna pochodziła z agregatów prądotwórczych. Teren koczowisk był zdewastowany i zanieczyszczony. Warunki, w jakich przebywali mieszkańcy obu osad, były bardzo trudne, nie mieściły się w przyjętych normach społecznych. Przeprowadzona w 2013 roku (na wniosek Urzędu Miejskiego Wrocławia) przez Powiatowego Inspektora Nadzoru Budowlanego inspekcja baraków zamieszkiwanych przez społeczność romską wykazała, że wzniesione przez Romów obiekty, jak również sposób ich eksploatacji, stwarzają zagrożenie dla życia i zdrowia osób w nich przebywających [...]" 22 lipca 2015 roku zgodnie z decyzją Powiatowego Inspektora Nadzoru Budowalnego we Wrocławiu Gmina Wrocław dokonała likwidacji koczowiska znajdującego się przy ul. Paprotnej.

Niedługo po likwidacji koczowiska Gmina Wrocław powierzyła Fundacji Dom Pokoju opracowanie i wdrożenie pilotażowego Programu na rzecz Romów Rumuńskich na lata 2016-2019, w ramach którego miały zostać podjęte działania zmierzające do rozproszenia koczowiska znajdującego się przy ulicy Kamieńskiego we Wrocławiu. Głównym celem programu był hausing obejmujący przygotowanie chętnych rodzin do zamieszkania poza terenem koczowiska oraz uzyskania przez nich samodzielności i niezależności. Pozostałe cele programu były nakierowane na wypracowanie modelów współpracy z mieszkańcami Wrocławia, w tym tworzenie lokalnych koalicji oraz opracowanie kampanii społecznej. Realizatorzy mieli także wypracować model współpracy ze społecznością romską nakierowany na jej usamodzielnienie. Działania te obejmowały regulowanie kwestii pobytowych Romów na terenie 
RP, poprawę stanu ich zdrowia, aktywizację zawodową, włączenie w system edukacji powszechnej oraz działania integracyjne. Model wdrożony został $\mathrm{w}$ formie międzysektorowego działania łączącego wszystkie zasoby dostępne we Wrocławiu, niezbędne do poprawy sytuacji rumuńskich Romów. Wykorzystano do tego system mieszkań treningowych, które pozyskano w całym mieście z rynku komercyjnego. Dzięki temu zima 2017/2018 była dla rumuńskich Romów ostatnią zimą na koczowisku. Wszystkie 150 osób zamieszkało w nowych miejscach, dzieci zostały zapisane do szkoły, a część dorosłych podjęła zatrudnienie. Jest to pierwsze tego typu i na taką skalę rozsiedlenie koczowiska romskiego w Europie od lat 60. Przez 2 lata programu realizatorzy mieli doprowadzić każdą rodzinę do samodzielności, do sprawnego korzystania z systemu (http://www.dompokoju.org [dostęp 21.11.2018]).

\section{Edukacja Romów we Wrocławiu}

Każdego roku do wrocławskich szkół uczęszcza około stu kilkudziesięciu uczniów pochodzenia romskiego. Warto wskazać, że we Wrocławiu jest kilka placówek, do których uczęszczają uczniowie romscy, jednak najwięcej z nich uczy się w Szkole Podstawowej nr 108. Dzieci romskie dodatkowo otrzymują wsparcie w ramach działalności świetlic środowiskowych o charakterze integracyjnym. Powstały bowiem miejsca integracji - centra aktywizacji, wzrosła świadomość rodziców romskich i dzieci o potrzebie edukacji, kadra pedagogiczna poznaje specyfikę ucznia romskiego i jego kultury, funkcjonują instytucje asystenta romskiego, nauczyciela wspomagającego, wyprawki szkolne i stypendia motywacyjne dla uczniów pochodzenia romskiego, godziny zajęć dodatkowych, wyrównawczych. Wciąż znikomy jest jednak udział Romów w edukacji przedszkolnej.

Sytuacja edukacyjna społeczności romskiej jest możliwa do przedstawienia i analizy z uwagi na zbieranie danych przez instytucje oświaty, a także deklarowanie pochodzenia w związku z przyznawanymi świadczeniami. Jeżeli chodzi o sferę pomocy materialnej uczniom romskim, to jest to przede wszystkim wciąż zakup wyprawek szkolnych. Funkcjonowały również stypendia motywacyjne i szkolne. Istotne wydaje się w tym zakresie wykorzystanie zasobów Miasta Wrocław, wsparcie finansowe z innych źródeł, pozyskiwanie zasobów ludzkich, doświadczenie w sprawie realizacji programów, istniejące instytucje (świetlice, jednostki miejskie), organizacje romskie, rodziny. Z dany dotyczących realizacji zwiększonej subwencji oświatowej w 2016 roku przygotowanych przez Urząd Miejski we Wrocławiu dotyczyło to 136 
uczniów szkół podstawowych (105), gimnazjów (24), ponadgimnazjalnych (7). Frekwencja wynosiła dla wszystkich poziomów nauczania nieco ponad $70 \%$, w tym najgorzej w gimnazjach, nieco ponad 60\%. Ogólnie 8 uczniów porzuciło naukę, a dla 16 organizowano nauczanie indywidualne.

Wspomnianym wcześniej problemem jest to, że dzieci pochodzenia romskiego nie korzystają z edukacji przedszkolnej. Wciąż brak jest informacji na temat promocji uczniów do klas następnych. Natomiast zapewne wartością dodaną programu od lat jest funkcjonowanie instytucji asystenta romskiego i nauczyciela wspomagającego edukację dzieci romskich. We Wrocławiu funkcjonowało 2 zatrudnionych asystentów edukacji romskiej i 12 nauczycieli wspomagających edukację uczniów romskich.

Świetlice środowiskowe na terenie Wrocławia prowadzą Stowarzyszenie Akson i Fundacja Integracji Społecznej PROM. Działania edukacyjne na rzecz dzieci ze społeczności romskiej to pomoc w odrabianiu lekcji, zajęcia sportowe, plastyczne, teatralne, komputerowe itp. Realizowany jest również zakup wyprawek szkolnych, stypendia motywacyjne.

Po analizie sytuacji potwierdziłem, że wciąż największymi problemami w tej sferze są: brak przygotowania przedszkolnego, nieznajomość języka polskiego, niewystarczająca świadomość potrzeby edukacji dzieci romskich, częste migracje, nieotrzymywanie promocji do klas programowo wyższych, sytuacja socjalna uczniów romskich, niechęć, nieprzychylność kadry pedagogicznej i administracyjnej, brak motywacji i wsparcia ze strony rodziców, kadra (nauczycieli wspomagających edukację w zakresie kompetencji edukacji międzykulturowej).

Poza tym należy wskazać na problemy z edukacją przedszkolną. Romowie nie spełniają często warunków formalnych (kryteria kwalifikacyjne, brak środków finansowych), nie mają tradycji oddawania dzieci na wychowanie "obcym”. Natomiast szkoły podstawowe i gimnazja to miejsca, gdzie dochodzi do sytuacji przerywania edukacji ze względów kulturowych i migracji. Problemami są również: konflikty rówieśnicze, różnice kulturowe rzutujące na udział w zajęciach (lekcje: wychowania fizycznego, biologia, „zielone szkoły") i kontakty rówieśnicze, wczesna aktywność ekonomiczna młodych Romów, wzrost obowiązków w domu rodzinnym, wczesne małżeństwa, macierzyństwo i ojcostwo, nierealizowanie oferty ścieżki edukacyjnej.

W zakresie szkolnictwa specjalnego można wskazać, że Wrocław stanowi pozytywny przykład realizacji dotychczasowych działań Programu. Mamy do czynienia z większą świadomością w zakresie kierowania dzieci do tych placówek. Poradnie psychologiczno-pedagogiczne mają specjalne programy słu- 
żące diagnozie dzieci romskich z wykorzystaniem narzędzi niewerbalnych.

Osobnym problemem w sferze edukacji jest kierowanie odpowiednich działań do dorosłych Romów (edukacja dorosłych). Zauważalny jest bowiem do tej pory brak dostatecznej informacji, świadomości, motywacji na temat perspektywy powrotu do systemu edukacji, brak możliwości uzupełnienia wykształcenia podstawowego, diagnozy potrzeb, umiejętności czytania i pisania wśród niektórych przedstawicieli tej społeczności. Istotna z tego punktu widzenia wydaje się zatem edukacja nieformalna wspomagana przez organizacje pozarządowe.

Stałym problem dotykającym społeczność romską w Polsce jest bezrobocie lub brak stałego zatrudnienia, sytuacja mieszkaniowa, bezpieczeństwo, przeciwdziałanie dyskryminacji oraz wykluczeniu społecznemu. Celowo pomijam w tekście te kwestie, które szczegółowo opisałem w raporcie. Ze względu na profil czasopisma zajmuje mnie edukacja.

\section{Wnioski z przygotowanego raportu}

W dziedzinie edukacji Wrocław stanowi pozytywny przykład realizacji dotychczasowych działań Programu rządowego. Największymi problemami w tej sferze są wciąż: brak przygotowania przedszkolnego, niedostateczna świadomość potrzeby edukacji dzieci romskich, częste migracje, brak informacji na temat promocji uczniów do klas programowo wyższych oraz często brak motywacji i wsparcia ze strony rodziców. Nie do przecenienia jest pozytywna rola instytucji wsparcia. Asystenci romscy i nauczyciele wspomagający edukację dzieci mają wyjątkowo trudne zadanie zapewnienia dzieciom wszechstronnej pomocy w kontaktach ze środowiskiem szkolnym oraz pomoc pracownikom szkół w kontaktach z uczniami. Rolą asystenta romskiego jest wsparcie emocjonalne uczniów romskich, pomoc nauczycielom wspomagającym oraz pedagogom w rozpoznaniu potrzeb i ewentualnych problemów uczniów. Do obowiązków asystentów należy też budowa dobrego kontaktu między rodzicami uczniów a szkołą, informowanie rodziców o przebiegu nauki oraz frekwencji uczniów i postępów w nauce. Istotne znaczenie ma wypracowanie systemu awansu dla asystentów romskich. Zadaniem nauczyciela jest bieżący nadzór nad postępami uczniów, prowadzenie zajęć wyrównawczych, pomoc w odrabianiu lekcji oraz stały kontakt z rodziną. Istotne jest, aby wzmacniać pozycję asystentów, dostarczać im nowych kompetencji, czynić z nich liderów lokalnych społeczności. Istnieje konieczność wzmocnienia działań administracji oraz policji w formie szkoleń uwrażliwiających 
na normy kulturowe Romów. Dodatkowo konieczne wydaje się przeprowadzenie szkoleń dla rad pedagogicznych z zakresu wielokulturowości - w tym kultury i zwyczajów romskich.

\section{Propozycje dobrych rozwiązań}

Rekomendowane są działania propagujące, a także zwiększające udział uczniów pochodzenia romskiego w edukacji przedszkolnej oraz rozwijanie edukacji nieformalnej zarówno dzieci, jak i dorosłych. Kluczowy jest również wzrost kompetencji międzykulturowych oraz podniesienie wiedzy o Romach wśród uczniów, studentów, pracowników służb publicznych oraz ogólnie społeczeństwa.

Należałoby rozwijać działania integrujące społeczność romską z większością. Ważnym aspektem jest rozwijanie idei oraz dalsze funkcjonowanie świetlic środowiskowych, edukacji przedszkolnej. Potrzebny jest w tych działaniach kontakt ze środowiskiem romskim, funkcjonowanie instytucji (asystent, nauczyciel, system stypendiów, ubezpieczenia, wyprawki, wyjazdy integrujące uczniów), współpraca z NGO i instytucjami publicznymi, psychologami, pedagogami, zewnętrzne źródła finansowania, godziny zajęć dodatkowych, stabilne finansowanie (zwiększona subwencja oświatowa), doświadczenie korzystania z różnych źródeł finansowania.

W obszarze szkolnictwa potrzebne jest wsparcie rodziny, jej integracja wewnętrzna i zewnętrzna. Na wszystkich poziomach edukacji niezbędne byłoby nabywanie kompetencji kulturowej mniejszości i większości, dialog międzykulturowy, przygotowywanie do kolejnych etapów edukacyjnych, opracowywanie ścieżki edukacyjnej, rozwijanie kompetencji międzykulturowych, kultury pisanej, wskazanie alternatywnych form spędzania wolnego czasu. Istnieje również potrzeba umożliwienia uzupełnienia edukacji dla dorosłych, także na poziomie szkoły podstawowej.

Propozycje rozwiązań to udział dzieci romskich w edukacji przedszkolnej, włączanie rodziców - zajęcia międzypokoleniowe - przedszkola raczkują$c e$, rozpatrzenie kryteriów rekrutacyjnych oraz sfery finansowania pobytu w przedszkolu, podniesienie świadomości wśród rodziców, przełamywanie barier kulturowych, kluby dziecięce, edukacja nieformalna, przedszkola integracyjne, zajęcia o takim charakterze, zaangażowanie do pomocy asystentów romskich edukacji przedszkolnej, szkolenia dla nauczycieli dotyczące pracy z dzieckiem dwukulturowym i dwujęzycznym. 
Na kolejnych poziomach edukacji należy wskazać na dalszą potrzebę nauki języka polskiego, programy autorskie skierowane do Romów w zakresie funkcjonowania na rynku pracy i w sferze biznesu (poszukiwanie zatrudnienia, rejestrowanie działalności gospodarczej, kształtowanie i rozwijanie kompetencji przedsiębiorczych), zajęcia wyrównawcze (dodatkowe), korepetycje, system motywacyjno-stypendialny, promowanie edukacji w działaniu, w wymiarze praktycznym, szkolenia dla doradców zawodowych dotyczące specyfiki aktywności zawodowej i zarobkowej społeczności romskiej.

Podsumowując, warto zwrócić szczególną uwagę na wyrównanie szans, zwiększenie świadomości i wzrost osiągnięć edukacyjnych uczniów oraz na zakres obowiązków asystentów edukacji romskiej - ich praca jest wielokrotnie niedoceniana zarówno ze strony społeczności romskiej, jak i ze strony pracowników szkoły. Zwiększenie uczestnictwa w edukacji uczniów oraz studentów pochodzenia romskiego. Rekomendowane działania to między innymi: wspieranie i promowanie edukacji wczesnoszkolnej dzieci romskich, organizowanie dodatkowych zajęć wyrównawczych z języka polskiego w przedszkolach i szkołach (szczególnie na wczesnym etapie edukacji) oraz pomoc w wyposażeniu uczniów romskich w wyprawki szkolne, w tym głównie w podręczniki, oraz ubezpieczaniu uczniów. Istotne jest również egzekwowanie realizacji obowiązku szkolnego. Cel ten można osiągnąć poprzez promowanie wysokiej frekwencji, na przykład za pomocą nagradzania uczniów o najwyższej frekwencji. Kolejne rekomendowane działania to wsparcie zadań skierowanych na kształtowanie i rozwój indywidualnych uzdolnień i umiejętności dziecka poprzez edukację kulturalną, historyczną i obywatelską, a także promowanie interaktywnych i innowacyjnych form kształcenia oraz podejmowanie działań zmierzających do zmniejszenia udziału uczniów romskich w szkołach specjalnych (współpraca z rodzicami, nauczycielami i asystentami, poradniami psychologiczno-pedagogicznymi). Widoczna jest również potrzeba kontynuacji i wdrażania programów stypendialnych dla uczniów i studentów romskich, a także nacisk na prowadzenie działań integracyjnych. Wskazane jest odchodzenie od zadań mających na celu prowadzenie zajęć wyłącznie dla uczniów romskich. Istotne jest objęcie systemowym wsparciem asystentów edukacji romskiej oraz nauczycieli wspomagających edukacji uczniów romskich. Niewątpliwie ważne jest także wspieranie edukacji dorosłych - kształcenie ustawiczne. Na końcu warto wspomnieć o potrzebie wsparcia infrastrukturalnego i remontowego lokali pełniących funkcje świetlic środowiskowych lub siedzib romskich organizacji pozarządowych. 


\section{Zakończenie}

Badane obszary życia grup romskich zamieszkujących we Wrocławiu wyraźnie wskazują problemy, z którymi borykają się polscy i rumuńscy Romowie. Opracowanie, które zostało zaprezentowane, zawiera diagnozę sytuacji Romów, ich problemów i potrzeb, a także dotychczas realizowanych zadań na rzecz społeczności romskiej we Wrocławiu. Jest oparte na raporcie przygotowywanym, jako ekspertyza, w odpowiedzi na zalecenia ECRI. Przedstawiam również cele projektowanych działań, w oparciu o tę diagnozę formułuję konkretne propozycje działań mogących doprowadzić do integracji. Oczywiście świadomość ograniczonej formy, jaką jest artykuł, nie pozwoliła na zaprezentowanie całego dostępnego materiału uzyskanego z udziałem zespołu przygotowującego raport. Wydaje się jednak istotne, aby wskazać na podjętą problematykę i ewentualną potrzebę projektowania tego typu polityk lokalnych przy udziale różnych aktorów społecznych w sferze edukacji.

Wielokrotnie w swoich tekstach wskazywałem na problemy integracji mniejszości romskiej. Potrzeba zmiany tego stanu rzeczy (z punktu widzenia kulturowo dominującej większości) niekoniecznie oczekiwana jest ze strony Romów. Główny cel tego typu polityk lokalnych to integracja społeczności romskiej, która odmiennie definiowana bywa przez Romów i przedstawicieli społeczeństw większości. Przez decydentów i konstruktorów oraz realizatorów działań na rzecz tej mniejszości rozumiana jest przede wszystkim jako umożliwienie Romom uzyskania wykształcenia i pracy, co miałoby zapewnić im dostęp do dóbr i usług publicznych. Tak rozumiana integracja zakłada głównie aktywność po stronie Romów. Błędnym założeniem jest to, że nierzadko dominuje optyka definiowania potrzeb z perspektywy społeczności większościowej, bądź bez konsultacji z Romami.

\section{Bibliografia}

Działania Administracji Publicznej na rzecz ochrony praw mniejszości romskiej w Polsce. Najwyższa Izba Kontroli. Warszawa 2015.

Kwadrans, Ł. 2015. Propozycje projektowania zmian w stereotypowym postrzeganiu Romów w Polsce XXI wieku na przykładzie działalności Fundacji Integracji Społecznej PROM. Parezja, 2 (4), ss. 49-65. 
Kwadrans, Ł. 2016. O potrzebie integracji społecznej Romów na przykładzie części edukacyjnej projektowanego programu lokalnego. Ruch Pedagogiczny. 1, ss. 119-131.

Kwadrans, Ł. 2013. Próba opisu i ewaluacji Programu rządowego oraz innych działań skierowanych do społeczności romskiej (na przykładzie gminy Świebodzice). W: Borek, P. red. Studia o Romach w Polsce $i$ w Europie. Kraków: Wydawnictwo Naukowe Uniwersytetu Pedagogicznego, ss. 70-90 .

Raport z badań. Społeczność romska we Wrocławiu. Wrocław 2013, niepublikowany.

Raport z badań nad potrzebami kulturowymi i edukacyjnymi Romów rumuńskich we Wrocławiu. Wrocław 2019, niepublikowany.

Romowie rumuńscy we Wroctawiu. Badania nad tożsamościa kulturowa $i$ zmianami w zakresie relacji społecznych zwiazanych $z$ edukacja podstawowa. Wrocław 2019, niepublikowany.

Uchwała Rady Ministrów z dnia 7 października 2014 r. w sprawie ustanowienia programu wieloletniego Program integracji społeczności romskiego w Polsce na lata 2014-2020. (Dz.U. z 2013 r. poz. 885, z późn. zm.).

https://www.coe.int/t/dghl/monitoring/ecri/country-by-country/poland/ pol-cbc-v-2015-20 pol.pdf (21.11.2018).

http://www.dompokoju.org (21.11.2018).

http://jednizwielu.pl (21.11.2018).

http://mniejszosci.narodowe.mswia.gov.pl (21.11.2018).

http://http/www.wroclaw2016.pl (21.11.2018).

\title{
An analysis of the educational situation of Roma in Wrocław in the context of the recommendation comprised in the $5^{\text {th }}$ monitored report of the European Commission against Racism and Intolerance (ECRI)
}

\begin{abstract}
The article is devoted to the analysis of the situation of the Roma community in Wrocław and the forms of support for Roma communities implemented in the city. The report was prepared by a team of experts in line with the recommendation of the fifth monitored report of the European Commission Against Racism and Intolerance (ECRI) concerning Poland, published on $9^{\text {th }}$ June 2015. The team analyzed the situation of the Roma community mainly on the basis of working meetings, interviews with social experts, monitoring visits and the data made available by the institutions.
\end{abstract}


The Author discusses the implemented forms of assistance to the Roma community and the impact of institutional support on the improvement of the quality of life of this group. Another undertaken issue is the diagnosis of the problems of Polish and Romanian Roma communities and their marginalization. The author of the article indicates the proposals of good practices and solutions to the problems faced by Roma groups living today not only in Wrocław.

Keywords: Roma, institutional support for Roma, education, Roma community integration

Translated by Łukasz Kwadrans 